\title{
YESMINA KHEDHIR
}

The Black Male Experience in Ta-Nehisi Coates's Between the World and Me and The Beautiful Struggle

Pro\&Contra 2

No. 2 (2018) 49-65. 



\begin{abstract}
Since the publication of his autobiographical essay Between the World and Me, the African American writer and journalist Ta-Nehisi Coates has garnered a wide readership as well as considerable recognition. Both in Between the World and Me (2015) and in his earlier memoir The Beautiful Struggle (2008), Coates traces his own experience as a black male growing up in a poor black neighborhood in West Baltimore. In his work, Coates tackles the major problems faced by black men in today's America, especially poverty, mass incarceration, drug addiction and dealing, urban violence and police brutality. He contends that the present predicament of black people, and black men in particular, can only be understood in light of the continuous dehumanization, marginalization, and destruction of black bodies. The paper aims to examine Coates' experience as a black male and to argue that despite his overt pessimism, Coates challenges hegemonic notions of black masculinity and subverts stereotypes about African American men by becoming a caring father and a conscious intellectual.
\end{abstract}

Keywords: Ta-Nehisi Coates, autobiography, black masculinity, black body, manhood

Since the publication of his autobiographical essay Between the World and Me (2015) written as a letter to his fifteen-year-old son, the African American writer and journalist Ta-Nehisi Coates has garnered a wide readership as well as considerable recognition. Both in his earlier memoir The Beautiful Struggle, A Father, Two Sons, and an Unlikely Road to Manhood (2008) and in Between the World and Me, Coates traces his own experience as a young black male growing up in a poor black neighborhood in West Baltimore. While The Beautiful Struggle focuses on Coates's childhood and his relationship with his family, his father in particular, Between the World and Me centers around the writer's adulthood alternating between the voices of Coates the author, Coates the son, and Coates the father. By opting for autobiography and memoir in communicating the black lived experience, Coates seeks not only to establish proximity with the reader, but also to anchor his works in an authentic African American literary tradition. Autobiography as a literary genre has been used by major canonical black writers. Starting mainly with slave narratives, autobiography has represented a means to report and provide real historical accounts of black lives pre- and post-emancipation, and more importantly to assert the black self and identity by giving agency and authority to the writer upon his/her own story and narrative. For instance, Toni Morrison in her article "The Site of Memory" underscores the significance of autobiography and memoir as an African American literary heritage and contends that the personal recollections of Frederick Douglass, Olaudah Equiano and Harriet Jacob (Linda Brent), among others, played a crucial role in exposing the evils of slavery, as well as in as- 
serting the humanity, "nobility" and "high-mindedness" of the writers. ${ }^{1}$ In the same vein, contemporary autobiographies and memoirs by male and female black writers contribute significantly to asserting the persisting legacy of slavery and Jim Crow, to exposing modern forms of racism and discrimination and to highlighting the continuing resistance and struggle among black individuals. In keeping with this African American literary tradition, Coates makes use of his own memories and reflections to communicate the experience of other black people, and especially other black men, in their struggle against the persisting legacies of racism and slavery in today's America.

Coates's books are full of anger, desperation and pain over the fact that black Americans continue to be the victims of American white supremacy and of the American Dream which was achieved, as Coates states, "through the pillaging of life, liberty, labor, and land; through the flaying of backs, the chaining of limbs, the strangling of dissidents; the destruction of families; the rape of mothers; the sale of children; and various other acts meant, first and foremost, to deny you and me the right to secure and govern our own bodies."2 Coates argues that the physical and psychological destruction of the black body is white America's primary policy, past and present, for asserting its power and dominance. However, through resistance and self-education, Coates promotes an alternative and progressive model of both blackness and masculinity ${ }^{3}$ by challenging hegemonic notions of black masculinity ${ }^{4}$ and subverting stereotypes about African American men by becoming a caring father and a conscious intellectual.

1 Toni Morrison, "The Site of Memory," in Inventing the Truth: The Art and Craft of Memoir, ed. William Zinsser (Boston-New York: Houghton Mifflin, 1995), 83-88.

2 Ta-Nehisi Coates, Between the World and Me (New York: Spiegel \& Grau, 2015), 8.

3 In her book Progressive Black Masculinities, Anetha D. Mutua explains that "[P]rogressive black masculinities are unique and innovative practices of the masculine self actively engaged in struggles to transform social structures of domination" (xi), that is black men, like black women, face and challenge different systems of oppression because both of gender and race. These gendered and racialized systems of domination often classify black men as either irresponsible/absent fathers or as criminal and dangerous individuals.

4 This point has also been taken and explained in a master's dissertation titled "Re-Presenting Black Masculinities in Ta-Nehisi Coates's Between the World And Me by Asmaa Aaouinti-Haris. Though the dissertation deals also with Coates's subversion of hegemonic stereotypes about black men and his promotion of a progressive model of masculinity, the textual analysis is restricted to Coates's Between the World and $M e$ (thus it does not address Coates's father as an influential model of black masculinity) and does not focus on the corporeal representation of the black male experience (the image of the destroyed black body) as well as on Coates's intellectual struggle.

Pro\&Contra 2 (2018) 49-65. 
In her seminal book The New Jim Crow: Mass Incarceration in the Age of Colorblindness, Michelle Alexander argues that "[t]oday mass incarceration defines the meaning of blackness in America: black people, especially black men, are criminals. That is what it means to be black." Alexander contends that the US criminal justice system and law are used as tools to detain and incarcerate as many as possible of particularly black males. She also claims that the constant criminalization of African American communities comes as a reaction to the civil rights and progress gained by black people during the Civil Rights movement in the 1960s and 1970s. Mass incarceration and the prison system are for Alexander the primary means for relegating blacks to a second-class position. Similar to Alexander's, Coates's books have been published in the midst of an epoch characterized by increasing police violence towards black people, as well as a surge in their numbers in the prison system. In his works, Coates affirms that institutional racism is a fact and that the justice system does not function in isolation from the country, but is a mere reflection of its racist policy when he claims that "[t]he truth is that the police reflect America in all its will and fear, and whatever we might make of this country's justice policy, it cannot be said that it was imposed by a repressive minority." ${ }^{6}$ For Coates, America's fear of losing its power continues to trigger its will and nourish its legacy of "destroying the black body."

Coates structures his essay Between the World and Me around an image that he describes as "so common" and "so old" to black people: the image of the destroyed black body. Like Ralph Ellison who starts The Invisible Man by asserting the invisibility of the protagonist's black body, Coates begins his essay by stressing the loss and destruction of his own body:

Last Sunday the host of a popular news show asked me what it meant to lose my body. The host was broadcasting from Washington, D.C., and I was seated in a remote studio on the far west side of Manhattan. A satellite closed the miles between us, but no machinery could close the gap between her world and the world for which I had been summoned to speak. ${ }^{8}$

This notion of the disembodiment and destruction of the black body is a recurrent trope throughout the book. For Coates, the black body has always been the target of American white supremacy. He claims that "[i]n America, it is a tradition to destroy the black body — it is a heritage." The words "tradition" and "heritage" assert both the

\footnotetext{
5 Michelle Alexander, The New Jim Crow: Mass Incarceration in the Age of Colorblindness (New York: The New Press, 2010), 192.

6 Coates, Between the World and Me, 79.

Coates, Between the World and Me, 9.

8 Coates, Between the World and $M e, 5$.

9 Coates, Between the World and Me, 103.
} 
historicity (in the sense of actuality and factuality) of the black body destruction and the ritualized repetitive nature of the practice. The destroyed black body could be interpreted in this sense as a site of "national historical memory" which symbolically links the past to the present. ${ }^{10}$ The enslaved body, lynched body and incarcerated body are three historical moments, distanced in time yet very closely related in African memory space. The destroyed body becomes thus a carrier of American history and memory and a testimony for its violence. Starting from slavery, through Jim Crow, up to current mass incarceration, Coates argues, America's policy of instilling fear and castrating the black body has aimed at gaining social control and asserting white dominance. In fact, this corporeal link between the past and the present is embedded in the essay's title itself. Coates's book Between the World and $M e$ is named after a poem of the same title written by Richard Wright depicting a horrifying scene of lynching and documenting the atrocities inflicted upon black bodies. By choosing "Between the World and Me" as a title to his book, Coates seems to suggest that the lynching image drawn by Wright in his poem is as valid today as it was in the past.

In Between the World and $M e$ Coates argues that the physical, mental, and social destruction of the black body has created a sense of incapability, powerlessness, and fragility among African Americans when he affirms: "The Conscious among us knew that the whole race was going down, that we'd freed ourselves from slavery and Jim Crow but not from the great shackling of minds." ${ }^{11}$ The present for Coates cannot be detached from the past because the former is a mere continuation and outcome of the latter. As a black man, Coates's feeling of being psychologically and socially emasculated and wounded reverberates throughout his letter to his son, as he claims: "I am wounded. I am marked by old codes, which shielded me in one world and then chained me in the next." ${ }^{\prime 2}$ Although Coates has never experienced slavery, Jim Crow or incarceration, he feels crippled and shackled by its memory. The undying traumatic effect of America's brutal history cannot be avoided because it inhabits the minds of black Americans and haunts their consciousness. The psychic wound is so deep and profound that it continues to bleed discreetly but incessantly, affecting how blacks perceive themselves and others. This cultural trauma is transmitted from one generation to another, so is the sense of being destroyed, emasculated and afraid, as Coates explains addressing his son: "And I am

\footnotetext{
${ }^{10}$ James B. Haile III, “Ta-Nehisi Coates's Phenomenology of the Body,” The Journal of Speculative Philosophy 31, no. 3 (2017): 494. (https://www.jstor.org/stable/10.5325/ispecphil.31.3.0493)

11 Ta-Nehisi Coates, The Beautiful Struggle: a Father, Two Sons, and an Unlikely Road to Manhood (New York: Spiegel \& Grau, 2008), 44.

${ }^{12}$ Coates, Between the World and Me, 103-104.
} 
afraid. I feel the fear most acutely whenever you leave me. But I was afraid long before you, and in this I was unoriginal. When I was your age, the only people I knew were black, and all of them were powerfully, adamantly, dangerously afraid. I had seen this fear all my young life."13 Coates suggests here that the destiny of black people is to live under a constant feeling of fear, fear about their own security and the security of their children and families. Subject to different forms of physical torture and punishment during slavery and Jim Crow, and to other forms of "frisking, detaining, beatings, and humiliation" 14 in today's America, black Americans remain trapped in a vicious circle of fear and impending danger. This collective feeling of fear affects how black males constitute their identity, define their masculinity, and engage in their social life. Coates's struggle as a black man consists of building his own personality and asserting his own identity against and within this overwhelming sense of fear. His struggle is triggered by a troubling question that he sets for himself, which is: "How do I live free in this black body?"15 Contrary to Baldwin's understanding of blacks' freedom as depending on a change in white people's perception and acceptance of black people when he claims that "[w]e cannot be free until they [white people] are free," 16 Coates contends that freedom should, in fact, be sought internally, in the black body itself, in blacks' history and blacks' definition of being and blackness. In other words, the answer to Coates's question should be the outcome of a self-reflective and self-indulging journey. Indeed, though Coates's journey from childhood to adulthood might be different than other black males', it certainly reflects some of the most common challenges and social constraints faced by the majority of black men growing up in a white-dominant society.

Bell Hooks maintains that African American males "are victimized by stereotypes that were first articulated in the nineteenth century but hold sway over the minds and imaginations of citizens of this nation in the present day." ${ }^{17}$ Two of these dominant stereotypes are the absent father and the violent and criminal black male. In his works, Coates subverts these stereotypes and provides an alternative model of the successful black male as he traces his path towards manhood both as a father and as a writer / intellectual. Three main factors have characterized and determined Coates's "road to manhood": the streets of Baltimore which symbolize violence, fatherhood, i.e., Coates's father William Paul Coates and Coates himself being a father, which symbolizes love and responsibility,

\footnotetext{
${ }^{13}$ Coates, Between the World and Me, 14.

${ }^{14}$ Coates, Between the World and Me, 9.

${ }^{15}$ Coates, Between the World and Me, 12.

${ }^{16}$ James Baldwin, The Fire Next Time (London: Michael Joseph, 1963), 21.

${ }^{17}$ Bell hooks, We Real Cool: Black Men and Masculinity (New York-London: Routledge, 2004), x.
} 
and finally Coates's Mecca, Howard University, which symbolizes consciousness and intellectual progress.

Coates was born and raised in West Baltimore in a poor black neighborhood during the "Crack Age" where guns, violence and black-on-black crime were rampant. In explaining the relationship between masculinity, race, and violence, Gail Garfield argues that " $[\mathrm{t}]$ he violent-black-male image and one of its contemporary derivations, the criminal-black-male, were formed during slavery. [...] Under slavery black men were 'forced to steal food and clothing to survive, forced to lie in order to cultivate reading and writing skills, forced to deceive in order to associate with the master class." ${ }^{18}$ Here, the connection between the past and the present is inevitable for understanding the current plight of the black male subject. The contemporary image of the criminal black man finds root in an older image assigned to blacks with a complete denial of the context in which it originated. Similarly, Coates provides a justification and explanation for black males' endorsement of violence when he claims:

The crews, the young men who'd transmuted their fear into rage, were the greatest danger. The crews walked the blocks of their neighborhood, loud and rude, because it was only through their loud rudeness that they might feel any sense of security and power. They would break your jaw, stomp your face, and shoot you down to feel that power, to revel in the might of their own bodies. ${ }^{19}$

The black male's sense of fear, powerlessness, and emasculation is turned to rage to compensate for an inner sense of fragility, weakness, and vulnerability. In addition, a certain longing for power, security, and control over their own bodies push black males to adopt the language of violence. Undoubtedly, Coates is not justifying criminality or violence, but hinting at some of its roots. After all - he seems to imply - this is the language with which blacks have continuously been addressed and treated. By internalizing the language of their oppressors and transforming their fear into another form of violence, black men become themselves a source of danger, not only to whites but to other black men (and women) as well. In this regard, bell hooks claims that "male violence is a central problem in our society. Black male violence simply mirrors the styles and habits of white male violence." ${ }^{20}$ Similarly, Garfield argues that the understanding of violence as

${ }^{18}$ Gail Garfield, Through Our Eyes: African American Men's Experience of Race, Gender, and Violence (New Brunswick-New Jersey-London: Rutgers University Press, 2010), 16.

${ }^{19}$ Coates, Between the World and $M e, 22$.

${ }^{20}$ hooks, We Real Cool, 61.

Pro\&Contra 2 (2018) 49-65. 
a crucial component of black masculinity is based on a white supremacist and patriarchal definition when he claims that:

[D] uring slavery, manhood was linked to whiteness, and, in turn, whiteness was linked to social power.... The ability of White men to whip and kill Black men at will and force them to witness violence against their female partners and children served not just as a tool of racial control, but violence also became deeply embedded in the very definition of masculinity. ${ }^{21}$

Despite trying to interpret and elucidate the causes behind the criminal and violent black male image, Coates asserts his resentment of violence and defines himself and his understanding of black masculinity against it when he claims:

I have never been a violent person. Even when I was young and adopted the rules of the street, anyone who knew me knew it was a bad fit. I've never felt the pride that is supposed to come with righteous self-defense and justified violence. Whenever it was me on top of someone, whatever my rage in the moment, afterwards I always felt sick at having been lowered to the crudest form of communication. ${ }^{22}$

By refusing to adhere to hegemonic notions of masculinity such as aggressiveness, violence and hypermasculinity, Coates promotes a progressive model of black masculinity and hence counters stereotypes associated with the black male subject. By negating the use of violence in his embodied discourse of the black male experience, Coates's offers an alternative representation of black manhood translated both in fatherhood and the intellectual struggle.

A Vietnam veteran, a former Black Panther, a black Nationalist who later adopted Afrocentism, William Paul Coates was a great influence on his sons, Coates in particular. Despite describing him as "flawed," "tough," and "fascist," 23 Coates feels grateful for the "blessing" of the presence of his father and acknowledges his significant contribution to the formation of his identity. The following are some of the phrases used by Coates to describe his father: "Dad was at war with his destiny. He was raising soldiers for all terrain. He preached awareness, discipline and confidence"24; "When I was young, my father was heroic to me, was all I knew of religion" "25; "Dad mostly thought of survival....

${ }^{21}$ Garfield, Through Our Eyes, 18.

${ }^{22}$ Coates, Between the World and Me, 65.

${ }^{23}$ Coates, The Beautiful Struggle, 20.

${ }^{24}$ Coates, The Beautiful Struggle, 20-21.

${ }^{25}$ Coates, The Beautiful Struggle, 205. 
Dad was responsible for a commune." ${ }^{26}$ As a Black Panther, William Paul Coates defines and understands the black male as a "warrior," a "soldier" always-already at war with his society, with the other and with his own self. He led a sober and strict life and adopted the Black Panther's ideals in raising his sons, particularly self-determination, self-defense, and responsibility. Driven by fear and anxiety to lose his child to the street, to jail or to drugs, William Paul Coates beats his son, Coates, if someone steals something from him; if he loses his keys or if he does not fight back when attacked. He emphasized the need and destiny to struggle for the black man. For him, born into a world defined by white standards, the black male's destiny is to fight to find a place, to survive and to be a man. In these terms, the black male comes into this world with the burden of responsibility, for himself, for his family and for his community. Thus, for Coates, initiation into manhood came at an early age. As a boy, he describes himself as the "child-man," placed somewhere between the innocence of a child and the maturity of a man. Coates's "road to manhood" came with a cost, that of missing a good part of his life, his innocence, his childhood. He declares "[e]ven after I got conscious, I'd felt I'd been robbed of time, that I had been isolated from a series of great childhood events." ${ }^{27}$ Coates's relationship with his father was a mixture of "hatred and complete reverence." ${ }^{28}$ For William Paul Coates, to be a man is to be tough, disciplined, and "Conscious." Consciousness means to educate oneself, to know black history, and to endorse and celebrate black culture and heritage. Thus, he insisted on educating his children and cultivating their knowledge of African American culture by pushing them to read Marcus Garvey, Malcolm X, Richard Wright, and Baldwin. Though Coates feels grateful to his father for making him a "Conscious" man and for saving him from the streets, violence, and drugs, he wanted to be a different father and to raise his child with more love.

Unlike his father, Coates's model of fatherhood is built on the ideals of love, tenderness, and softness. Coates chooses to raise his son away from "toughness" and the burden of responsibility that black boys are born with. Addressing his son, he declares: "I have no desire to make you 'tough' or 'street,' perhaps because the 'toughness' I garnered came reluctantly. I think I was always somehow aware of the price." ${ }^{29}$ Coates wants to trace another future for his son, a future that is not shaped by fear and the urgent need to protect his body. However, by writing a letter with an overt pessimistic voice laced with an overwhelming sense of fear, Coates ends up transmitting to his son the traumatic feeling

\footnotetext{
${ }^{26}$ Coates, The Beautiful Struggle, 78.

${ }^{27}$ Coates, The Beautiful Struggle, 207.

${ }^{28}$ Coates, The Beautiful Struggle, 20.

${ }^{29}$ Coates, Between the World and Me, 24.
} 
he felt in his own father and encountered in all the books he read and the kids he grew up with in his poor neighborhood in West Baltimore. He tells him: "I did not want to raise you in fear and false memory. I did not want you forced to make your joy and blind your eyes. What I wanted for you was to grow into consciousness. I resolved to hide nothing from you." ${ }^{30}$ Yet, by insisting on the importance of consciousness (knowing black history) and on the inevitability of the struggle, Coates ends up tracing the same path for his child that his father traced for him.

Despite distancing himself partly from his father's ideal of the revolutionary, tough and insurgent black man, Coates has a similar understanding of the conventional patriarchal role of a father. By insisting on the importance of being a good father and feeling an urgent need as "the father of a black boy [...] and the husband of a black woman" 31 to protect his child and his wife, Coates seems to suggest that the black man has a double responsibility as a father because of his skin color. He warns his son: "You have to man up,' we tell our sons, 'Anyone can make a baby, but it takes a man to be a father." 32 Coates here makes a connection between the true sense of masculinity and responsibility as a father and perceives the lack of masculine parental authority and the absence of fathers as fundamental to the problem of urban black communities. By presenting fatherhood as a crucial component of the ideal black man, Coates seems to suggest that racial uplift needs socially responsible men.

The third and last factor of significant contribution to Coates's "road to manhood" is Mecca: Howard University, which symbolizes knowledge and the intellectual struggle for Coates. As a student, Coates spent most of his time at Howard's library excavating the great works of African American history and literature. Pushed both by his father and by his own curiosity to know more about the African American history, literature, art, and culture, Coates's consciousness was alerted to the beauty of African American culture. He claims:

I knew that I was literally walking, in the footsteps of all the Toni Morrisons and Zora Neale Hurstons, of all the Sterling Browns and Kenneth Clarks, who'd come before. The Mecca - the vastness of black people across space-time - could be experienced in a twenty minute walk across campus. [...] Through the Mecca I saw that we were, in our own segregated body politics, cosmopolitans. ${ }^{33}$

\footnotetext{
${ }^{30}$ Coates, Between the World and Me, 111.

${ }^{31}$ Coates, Between the World and Me, 124

32 Coates, Between the World and Me, 66.

${ }^{33}$ Coates, Between the World and Me, 41-42.
} 
In a rather similar way to Malcom X's hajj "serv[ing] to authenticate the self spiritually, culturally, and socially," ${ }^{34}$ Coates, through his search, discovered the complexity of the African American identity, its "fractal structure" 35 and "double-consciousness," strated respectively by Paul Gilroy in his book The Black. Atlantic - asserting the transnationality and transculturality of the African American identity — and in Du Bois's The Souls of Black Folk — showing that the black subject experiences a sense of displacement and inability to fit into two different cultures: the African American and the American cultures. By studying the African American identity, Coates understood that to be black in America is to be at the same time inside, and outside, whole and part, American and African, Caribbean and European. In fact, the complexity, multipolarity and transnationality of the African American identity are, for Coates, the very source of its beauty, "historical and cultural, incarnate." ${ }^{37}$ Here, Coates seems to suggest that the answer to his profound question "How do I live free in this black body?" 38 is that by acknowledging the beauty of that black body, by endorsing its blackness and seeing the best and most cheerful part of it, despite all the pain and trauma that that black body carries. By stressing the need to recognize the beauty of the African American physical and cultural body, Coates refers indirectly to the "Black is beautiful" cultural movement that swept the US in the 1960s and echoes Malcolm X (in his speech "Who Taught You to Hate Yourself") 39 who is one of the most influential and inspirational figures in Coates's intellectual struggle.

Malcolm X is the symbol of the free-black-man for many young black men and women. He symbolizes freedom and manliness. Elridge Cleaver devoted a whole chapter to the memory of Malcolm X and quoted Ossie Davis in his eulogy of Malcolm: 'Malcolm was our manhood, our living, black manhood. This was his meaning to his people." ${ }^{40}$ Bell hooks claims: "Malcolm X embodied black male refusal to allow his identity to be defined by a system of race, gender, and class domination. He was the example that young

${ }^{34}$ Péter Gaál-Szabó, “'Mold[ing] people of all colors into one vast family:' Malcolm X and Interculturation.” Eger Journal of American Studies 14 (2014): 38.

35 Paul Gilroy, The Black Atlantic: Modernity and Double Consciousness (London-New York: Verso, 1993), 4.

${ }^{36}$ W.E.B. Du Bois, The Souls of Black Folk, ed. Brent Hayes Edwards (Oxford-New York: Oxford University Press, 2007), 8.

${ }^{37}$ Coates, Between the World and Me, 49.

${ }^{38}$ Coates, Between the World and Me, 12.

${ }^{39}$ Malcolm X, "Who Taught You to Hate Yourself," filmed May 5, 1962, https://www.youtube.com/ watch? ${ }_{\mathrm{v}}=\mathrm{kboP} 3 \mathrm{AWCTk}$ ("Who taught you to hate the color of your skin? Who taught you to hate the texture of your hair? Who taught you to hate the shape of your nose and the shape of your lips? Who taught you to hate yourself from the top of your head to the soles of your feet? Who taught you to hate your own kind?").

${ }^{40}$ Elridge Cleaver, Soul on Ice (New York: Dell Publishing, 1992), 84. 
black folks in the sixties followed as we struggled to educate ourselves for critical consciousness." ${ }^{41}$ Similarly, For Coates:

The best parts of Malcolm pointed the way. Malcolm always changing, always evolving toward some truth that was ultimately outside the boundaries of his life, of his body. I felt myself in motion, still directed toward the total possession of my body. [...] Malcolm spoke like a man who was free, like a black man above the laws that proscribed our imagination. I identified with him. ${ }^{42}$

Coates explains that his identification with Malcolm X should not be understood as a love or preaching of violence. He loves Malcolm because Malcolm is not overwhelmed by fear like all the black men he encountered both as a child and as an adult, because Malcolm is in control of his own body, unlike all the other black men, unlike Coates himself. Shortly, Malcolm represents, for him, the example of the ideal black man and leader of the sixties that black Americans need the most in the twenty-first century.

Coates's road to manhood was determined by several factors, fatherhood, his life in Baltimore and his intellectual experience at Howard University. Throughout his journey from childhood to adulthood, Coates learned a lesson he saw as a young boy in his own father: the inevitability and importance of the struggle for black people. The struggle for Coates is not in fighting white supremacy, but rather in questioning, knowing and endorsing the beauty of the African American culture and identity. Thus, he qualifies it as the "Beautiful Struggle":

If my life ended today, I would tell you it was a happy life - that I drew great joy from the study, from the struggle to which I now urge you. You have seen in this conversation that the struggle has ruptured and remade me several times over - in Baltimore, at The Mecca, in fatherhood $[\ldots]$ the changes have taught me how to best exploit that singular gift to study, to question what I see, and to question what I see after that, because the questions matter as much, perhaps more than, the answers. ${ }^{43}$

Coates's struggle is an intellectual one. It could be defined as both the struggle of a black man and of a black writer. By invoking and endorsing the entire history of black culture and seeing beauty in all the literary figures and art movements that helped shape black culture and identity (slave narratives, Harlem Renaissance, Afrocentrism, Black Power, Black nationalism, Black Panthers, Black Muslims, and Civil Rights movement, etc.), Coates

\footnotetext{
${ }^{41}$ hooks, We Real Cool, x.

${ }^{42}$ Coates, Between the World and Me, 48-49.

${ }^{43}$ Coates, Between the World and Me, 115-116.
} 
seems eager to find his place as a writer among them, yet this also reveals a certain nostalgia for the past despite all its traumatic memory. A certain feeling of being lost that followed the Civil Rights movement of the 1960s and 1970s is implied in Coates's essay. Ellis Cose explains this when he contends that "[m]any of us are lost in this America of the twenty-first century. We are less sure of our place in the world than our predecessors, in part because of our options, our potential choices, are so much grander than theirs. So, we are trapped in a paradox." ${ }^{4}$ In the so-called post-racial era, blacks' dilemma is that although they have better chances at succeeding, they feel shackled and crippled by the continuing legacies of the past, by the traumatic memory that constitutes, ironically, at the same time the very source of their pain and pride. The paradox here is that by forgetting a painful past and endorsing a progressive present, black people would betray their ancestors and lose the true meaning of struggle, hence their identity and sense of existence. And by keeping the memory of the past alive, they would remain prisoners of a trauma that will continue to determine their present; no matter how great the progress is. In relation with this, Coates emphasizes the importance of remembering and the danger of forgetting. Warning his son against forgetfulness, Coates says:

Never forget that we were enslaved in this country longer than we have been free. Never forget that for 250 years black people were born into chains - whole generations followed by more generations who knew nothing but chains. You must struggle to truly remember this past in all its nuance, error and humanity. [...] You cannot forget how much they took from us and how they transfigured our very bodies into sugar, tobacco, cotton and gold. ${ }^{45}$

Because collective and cultural memory is essential for ensuring the continuity and coherence of the African American identity and because "memory reactivated has the facilitating power to point into new directions of self-conceptualization; even if containing and displaying cultural trauma, it can also offer modes to rework it," ${ }^{46}$ Coates insists on transmitting the memory of the past with all its "nuance, error and humanity" to the next generations. Also, as a black subject, Coates feels a "duty to remember" by which he "keeps alive the memory of suffering over against the general tendency of history to

\footnotetext{
${ }^{44}$ Ellis Cose, The Envy of the World: on Being a Black Man in America (New York: Washington Square Press, 2003), 11.

${ }^{45}$ Coates, Between the World and Me, 70.

${ }^{46}$ Péter Gaál-Szabó, "Cultural Memory and Countering History Through Memory in Martin Luther King, Jr.'s Sermons," in Intertextuality, Intersubjectivity and Narrative Identity (Newcastle: Cambridge Scholars, 2017), 87.
}

Pro\&Contra 2 (2018) 49-65. 
celebrate victors"' 47 and creates a counter-narrative by which he revises dominant narratives and honors his ancestors. Thus, the struggle that Coates calls for is the struggle to transmit the African American cultural memory, to nurture it and to seek freedom for the destroyed body by resisting forgetfulness while appreciating blackness.

In his two autobiographical books, Between the World and Me and The Beautiful Struggle, Coates depicts his own experience as a black male and his journey from childhood to manhood. His experience is undoubtedly different than the experience of other black males, but it certainly reflects what it means to be a black man in today's America. Coates exposes some of the major problems and challenges facing black males today, especially in poor urban communities, namely absent fathers, police brutality, the random killing of young black males, and high incarceration rates. Coates's journey to manhood was different than most of the black children of his neighborhood. Because Coates has a father who saved him from the streets, who pushed him to read, to grow into consciousness, and to engage in a meaningful struggle for knowing and embracing black history and culture, he became a good father and a "conscious" intellectual, proud and aware of the true meaning of his African American identity. By performing a different and progressive model of masculinity, Coates challenges the hegemonic ideals associated with black men and subverts contemporary and mainstream stereotypes that represent black men as irresponsible fathers and dangerous criminals.

${ }^{47}$ Barbara A. Mitzal, Theories of Social Remembering (Maidenhead. Philadelphia: Open University Press, 2003), 146. 


\section{References}

Alexander, Michelle. New Jim Crow: Mass Incarceration in the Age of Colorblindness. New York: The New Press, 2010. https://doi.org/10.1111/j.1365-2796.2009.02206.x

Baldwin, James. The Fire Next Time. London: Michael Joseph, 1963.

Cleaver, Eldridge. Soul on Ice. New York: Dell Publishing, 1992.

Coates, Ta-Nehisi. Between the World and Me. New York: Spiegel \& Grau, 2015.

Coates, Ta-Nehisi. The Beautiful Struggle: a Father, Two Sons, and an Unlikely Road to Manhood. New York: Spiegel \& Grau, 2008.

Cose, Ellis. The Envy of the World: on Being a Black Man in America. New York: Washington Square Press, 2003.

Du Bois, W. E. B. The Souls of Black Folk, edited by Brent Hayes Edwards. Oxford: Oxford UP, 2007.

Gaál-Szabó, Péter. "Cultural Memory and Countering History Through Memory in Martin Luther King, Jr.'s Sermons." In Intertextuality, Intersubjectivity and Narrative Identity, edited by Péter Gaál-Szabó, 77-90. Newcastle: Cambridge Scholars, 2017.

Gaál-Szabó, Péter. “'Mold[ing] people of all colors into one vast family:' Malcolm X and Interculturation.” Eger Journal of American Studies 14 (2014): 29-40.

Garfield, Gail. Through Our Eyes African American Men's Experience of Race, Gender, and Violence. New Brunswick-New Jersey-London: Rutgers UP, 2010.

Gilroy, Paul. The Black Atlantic: Modernity and Double Consciousness. London-New York: Verso, 1993.

Iii, James B. Haile. "Ta-Nehisi Coates's Phenomenology of the Body." The Journal of Speculative Philosopby 31, no. 3 (2017): 493-503. Web. https://doi.org/10.5325/ jspecphil.31.3.0493

Hooks, bell. We Real Cool: Black Men and Masculinity. New York-London: Routledge, 2004. https://doi.org/10.4324/9780203642207

Malcolm X. "Who Taught You to Hate Yourself." YouTube. Video File. May 5, 1962. https://www.youtube.com/watch?v=kboP3AWCTkA 
Mitzal, Barbara A. Theories of Social Remembering. Philadelphia: Open University Press, 2003.

Morrison, Toni. "The Site of Memory." In Inventing the Truth: The Art and Craft of Memoir, edited by William Zinsser, 83-102. Boston-New York: Houghton Mifflin, 1995.

Mutua, Athena D., ed. Progressive Black Masculinities. New York: Routledge, 2006. https://doi.org/10.4324/9780203961438 